\title{
Experimental Study of Cohesive Embankment Dam Breach Formation due to Overtopping
}

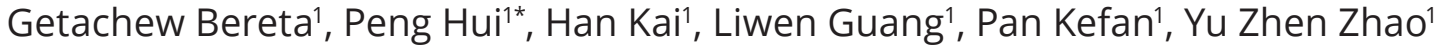 \\ 1 Department of Hydraulic Engineering, College of Hydraulic and Environmental Engineering, China Three Gorges University, \\ 443002, Yichang, Hubei Province, China \\ * Corresponding author, e-mail: shyb@ctgu.edu.cn
}

Received: 19 June 2019, Accepted: 07 December 2019, Published online: 03 February 2020

\begin{abstract}
The recurrent floods in recent decades have imposed a challenge of embankment dam breaching, which needs great attention through improved design methods that are based on risk approach, the evacuation plans for people at risk, etc. In this study, based on the small-scale model tests a series of experiments were conducted to determine the breaching process of cohesive embankment dam using a simplified physical based breach model due to overtopping; the breach process observed during tests in the laboratory and the results from analyzed parameters are described. Five dam models, three of which were constructed with homogenous clay soil while two were sandy-clay mixture tested. The heights of the embankments dam were $0.45 \mathrm{~m}$, and the widths at the crest were $0.20 \mathrm{~m}$. The data from these examinations indicated that headcut erosion played an important role in the process of breach development. Initiation of erosion, flow shear erosion, sidewall bottom erosion, and distinct soil mechanical slope mass failure from the headcut vertically and laterally were all observed during these tests. In this physical based experimental model, the initial scouring position calculated by applying a hydraulic method, the broad crested weir formula used for breaching flow discharge and flow velocity computed based on breach flow discharge. The stability of the side slope failures was estimated by comparing the resisting and deriving force. Further, using data from laboratory experiments, the calculated peak breach discharge, breach characteristics times, breach widths, and breach flow velocity generally agreed well with the measured data and also the knowledge acquired from observed breach process at several stages. Finally, the accuracy of model was checked by root-mean-square-error.
\end{abstract}

\section{Keywords}

cohesive embankment dam, headcut, overtopping, breach parameters, initial scour position

\section{Introduction}

The most difficulty of embankment failure is breaching due to overtopping and/or seepage which leads to piping. When the part of embankment is actually removed away it can leave a large opening for water to flood the land protected by the embankment. A breaching can be a gradual or sudden failure that is caused by headcut erosion and/ or surface erosion [1]. Overtopping may be caused by a variety of reasons such as inadequate design, large inflow into reservoir from upstream of dam, extreme wave and surge, settlement of embankment crest, debris blockage of outlets, service life, and an increase in global warming [2]. Moreover, the nature of construction materials for these structures is highly susceptible to failure by overtopping. For instance, in China from 1954 to 2014, there have been 3530 dam breach accidents occurred, from these over $50 \%$ of dam failures were due to overtopping, and the homogenous cohesive dams accounted for about $85 \%$ of the total failures [3]. Therefore, understanding the breach development in embankments and modeling the breach expansion process is of significant to the design method of embankments based on a risk-approach, the development of early warning system for embankment failures, to the evacuation plans of people at risk and property. To assess the consequence of homogeneous cohesive dam failure by overtopping, the breach mechanism numerical and physical or experimental modeling technic is very essential.

The occurrence of headcut erosion plays a significant role in a breaching process of a cohesive embankment. As many researchers concluded from historical observations and studies of cohesive materials at different scales indicated that headcut is the leading process in cohesive embankment breaching [4-8]. During the past decades, 
several experiments on the breach of embankments have been conducted [9]. These experiments include both small-scale and large-scale tests in the laboratory and field respectively. Nevertheless, due to numerous factors influencing the breaching formation and development in embankments such as structure and profile of embankment, type of construction material, type of foundation, and cause of failures have complicated the process [10]. Notwithstanding, numerous research or experiments conducted and the knowledge acquired thus far, the consensus and understanding of embankment breaching mechanism is still not satisfactory.

Zhu et al. [9], discussed the morphological observations of embankment test conducted by Hahn et al. [11] which was emphasized on the nature of breach morphology, including, formation characteristics, general morphological development, and rate of change during the overtopping events. Herein or in this experimental test, not only the morphological breach development process, also comprises the numerical computation of breach parameters, peak out flow and including the measured and calculated breach flow velocity. In addition, the detail discussion was carryout in each stage of morphological variations which were supported by the parameters based on the results obtained.

According to ASCE/EWRI Task Committee [2] and $\mathrm{Wu}$ [12], dam breaching models can be classified as a parametric, physically based, and detailed multidimensional physical based breach models. Parametric models for estimating dam breach characteristics use statistically derived regression equations, such as peak outflow, final breach width breach formation time. Physically-based models usually simplify the breach cross-section as a rectangular, triangle, or trapezoid and simulate the breach flow by using the broad-crested weir equation. Detailed multidimensional physical based breach models simulates embankment breaching in more detail the morphodynamic and flow processes. Because breach flows are usually in mixed flow regimes with discontinuities, the numerical schemes often used are 1D, 2D or 3D discretization of the breach in space and time.

In the recent year several breaching models like; HR BREACH [13], NWS BREACH [14], DL Breach [15], BRESZHU [16], WinDAM [7], Zhong et al. [3], etc. were developed based on physical models, mostly simplified with different breach cross-sections and simulated the breach flow by using the broad-crested weir equation. The validation and calibration of most of these models is the continuous process, however, it is difficult due to the lack of good empirical data. Hence, to improve the awareness of the process of embankment dam breaching as well as compute the breach parameters, and ultimately collect data for the validation of embankment breach simplified model, five laboratory tests were conducted.

In this paper, a series of experiment were conducted in a flume to determine the breaching processes and summarize the observed results from these tests. Failure was generated based on small-scale laboratory model tests to simulate the cohesive embankment breaching process in the form of headcut migration for compacted clay soil and sandy-clay soil. In the model, the initial scouring position was calculated by using a hydraulic method, while the broad crested weir formula was utilized to compute breach flow discharge that was used to calculate flow velocity, and the stability of breach slope was estimated by the limit equilibrium method. Based on the model, an iterative method was adopted to compute the interaction process of soil and water at each time step. The technical details and validations by laboratory test of the models are described in the following sections.

\section{Methods, materials and experimental setup \\ 2.1 Materials and experimental set up}

The tests were conducted in the straight parts of trapezoidal flume that is in the experimental hall of Laboratory of Hydraulic Test Center of China Three Gorges University. It has the total length $28 \mathrm{~m}$; average top width $1.6 \mathrm{~m}$; average depth $0.6 \mathrm{~m}$ (i.e. upstream storage basin with depth of $0.7 \mathrm{~m}$ and downstream straight flume with depth of $0.5 \mathrm{~m}$ ); and bottom width $0.7 \mathrm{~m}$. The upper part of the flume is connected to a storage basin with a capacity of $15 \mathrm{~m}^{3}$. The model was constructed on the downside compartment of straight flume that has the length of $13 \mathrm{~m}$, Fig. 1 experiment site layout, Fig. 2 is the cross-sectional layout of the dam model and longitudinal section of the experimental flume. During the test, between the experimental model and the flume curve, there was enough space and a structure for smooth transitional flow to the straight part, the bed slope is zero, hence, the curve has no effect on the flow (i.e. the upper flume curve used as the supplementary reservoir storage for the tests). In addition, the curve's and slope's influence were not considered in the breach experiment.

A total of five tests were conducted, three with an embankment constructed with clay (tests $\mathrm{T}_{1}, \mathrm{~T}_{2}$ and $\mathrm{T}_{4}$ ), two with embankments constructed with sandy-clay mixture (tests $\mathrm{T}_{3}$ and $\mathrm{T}_{5}$ ). The soil samples were taken and tests were conducted at China Three Gorges University, Geotechnical 
Laboratory to characterize the geotechnical parameters as shown by the results presented in Table 1 . The main factors considered were upstream inflow and outflow discharge, Q, density (compactness), $\rho$, water content, $\omega$, of dam materials, etc. All the five tests embankment configuration and dimensions are summarized in Table 1, and in Figs. 1 and 2. The height of each embankment dam was set according to flume channel dimension to allow observation of the breach erosion process which was recorded by the cameras.

It was constructed by successively placing soil in horizontal loose lift layers about $0.1 \mathrm{~m}$ thick for all tests, $10 \mathrm{~kg}$ compactor was used to compact each loose layer. Special attention was paid to compaction of against the two sidewalls. After the embankment was built, careful trimming of the embankment was done to attain designed embankment profile.

Two water gauges were placed at the upper side of the dam model at point G1 and G2 (see Figs. 1 and 2 and Table 1). While the Velocity changes and discharge near the breach were measured by an Acoustic Douppler Velocimeter (ADV), the measurements were taken at three points (i.e. right, middle and left of breach) and for the analysis the average value was used, and the breaching process was recorded by two cameras fixed to a tripod near the dam model at points $\mathrm{C} 1$ and $\mathrm{C} 2$ (Figs. 1(a) and 1(b)). To facilitate reading of the embankment dam breaching profile from recorded picture and videos, grid

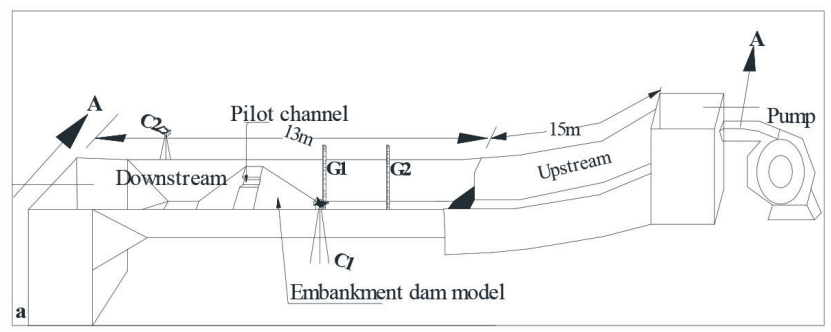

(a)

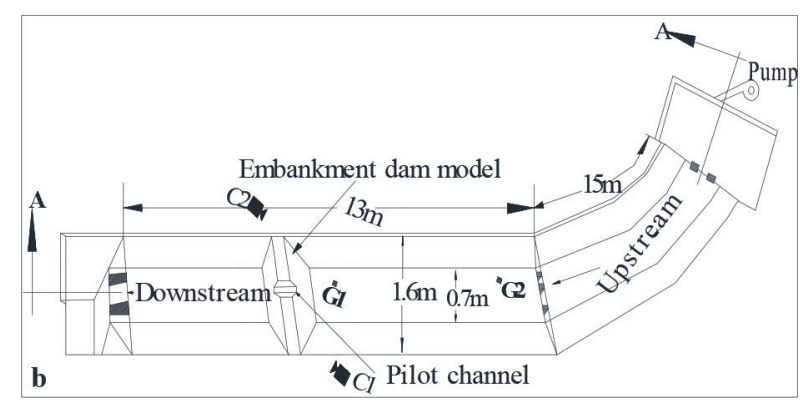

(b)

Fig. 1 (a) 3D orientation and (b) Plan view of experimental flume and embankment

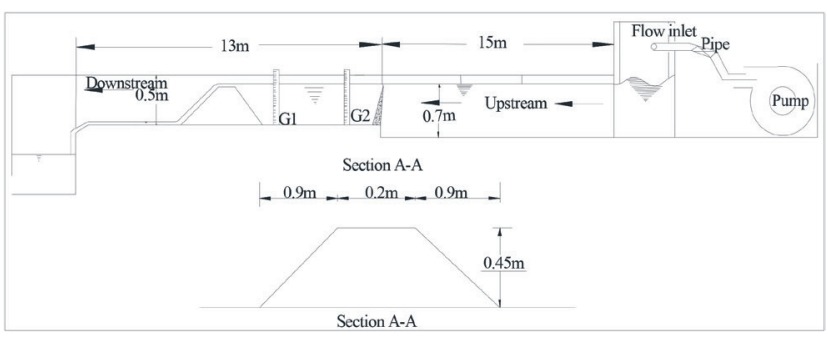

Fig. 2 Section view experimental flume and embankment dam

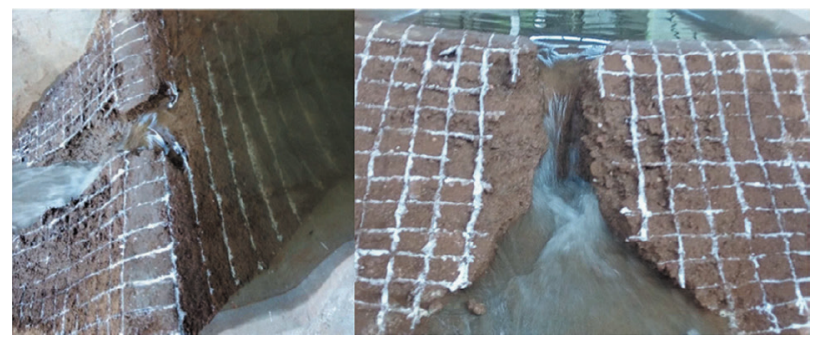

Fig. 3 Breaching process during laboratory test

lines were drawn on the down side of embankment at common distance of $10 \mathrm{~cm}$ and similarly the upside slope with horizontal lines (see Fig. 3).

Before starting the test, the water was first pumped into the storage basin and then the upstream section was also filled through the water inlet, after fill of required amount of water, the overtopping flow test was started. The breaching development consider both vertical and widening channel.

\subsection{Methods}

Failure due to overtopping, the breaching process of cohesive embankment dams based on laboratory experiment results, the methodology expressed numerically as follows:

\subsubsection{Hydrodynamic}

The initial scouring position at downstream side of the dam

In case of overtopping flow, the initial scouring position commonly appears at the downstream toe. In this study, initial scouring position was considered, and calculated by the formula proposed by Visser [17]:

$l_{m}=\frac{2.5\left(F^{2} r m-1\right) d_{m}}{\tan \beta}$,

where: $\beta$ is the inclination angle of the downstream slope of the dam, $d_{m}$ is the normal water depth on that slope and the subscript ' $m$ ' refer to the equation is flow condition, and $F r_{m}$ is the Froud number at $\mathrm{X}$ is equal to $l_{m}$. Froud number is given by: 
Table 1 Parameters and experiment case, and measured water level at point G1 and G2

\begin{tabular}{|c|c|c|c|c|c|c|c|c|c|c|}
\hline \multirow{2}{*}{\multicolumn{6}{|c|}{ Parameters }} & \multicolumn{5}{|c|}{ Experiment } \\
\hline & & & & & & $\mathrm{T} 1$ & $\mathrm{~T} 2$ & $\mathrm{~T} 3$ & $\mathrm{~T} 4$ & $\mathrm{~T} 5$ \\
\hline \multicolumn{6}{|c|}{ Dam height (m) } & 0.45 & 0.45 & 0.45 & 0.45 & 0.45 \\
\hline \multicolumn{6}{|c|}{ Dam length (m) } & 1.85 & 1.85 & 1.85 & 1.85 & 1.85 \\
\hline \multicolumn{6}{|c|}{ Crest width (m) } & 0.2 & 0.2 & 0.2 & 0.2 & 0.2 \\
\hline \multicolumn{6}{|c|}{ Upstream slope (V/H) } & $1: 2$ & $1: 2$ & $1: 2$ & $1: 2$ & $1: 2$ \\
\hline \multicolumn{6}{|c|}{ Downstream slop $(\mathrm{V} / \mathrm{H})$} & $1: 2$ & $1: 2$ & $1: 2.5$ & $1: 2$ & $1: 2.5$ \\
\hline \multicolumn{6}{|c|}{ Initial breach depth (m) } & 0.05 & 0.05 & 0.05 & 0.05 & 0.05 \\
\hline \multicolumn{6}{|c|}{ Initial breach width (m) } & 0.2 & 0.2 & 0.2 & 0.2 & 0.2 \\
\hline \multicolumn{6}{|c|}{ Reservoir storage $\left(\mathrm{m}^{3}\right)$} & 25 & 24 & 24 & 24 & 24 \\
\hline \multicolumn{6}{|c|}{ Reservoir surface area $\left(\mathrm{m}^{2}\right)$} & 32 & 28 & 28 & 28 & 28 \\
\hline \multicolumn{6}{|l|}{$d_{50}(\mathrm{~mm})$} & 0.006 & 0.025 & 0.035 & 0.006 & 0.035 \\
\hline \multicolumn{6}{|l|}{$C$ (Kpa) } & 22 & 20.5 & 18.7 & 22 & 18.7 \\
\hline \multicolumn{6}{|l|}{$\phi(0)$} & 25.01 & 22.26 & 20.23 & 25.01 & 20.23 \\
\hline \multicolumn{6}{|l|}{ Clay ratio } & 0.4 & 0.35 & 0.25 & 0.4 & 0.3 \\
\hline \multicolumn{6}{|c|}{$C T\left(\mathrm{~m}^{-1 / 6} \mathrm{~s}^{-2 / 3}\right)$ in headcut migration } & 0.0016 & 0.0026 & 0.0025 & 0.013 & 0.0025 \\
\hline \multicolumn{6}{|c|}{ Inflow Q $\left(\mathrm{m}^{3} \mathrm{~S}^{-1}\right)$} & 0.004 & 0.006 & 0.0052 & 0.008 & 0.0063 \\
\hline \multicolumn{6}{|c|}{ Incremental Q $\left(\mathrm{m}^{3} \mathrm{~S}^{-1}\right)$} & 0.0035 & --- & --- & --- & --- \\
\hline \multicolumn{6}{|l|}{$w(\%)$} & 13 & 11 & 8 & 13 & 8 \\
\hline \multicolumn{6}{|l|}{$\rho\left(\mathrm{kgm}^{-3}\right)$} & 2097 & 2038 & 2032 & 2187 & 2111 \\
\hline$\rho_{d}\left(\mathrm{kgm}^{-3}\right)$ & & & & & & 1952 & 1471 & 1673 & 1952 & 1673 \\
\hline & & & & d water & (in met & point G1 & G2 & & & \\
\hline Time & & & & & & & & & & \\
\hline (hr) & G1 & G2 & G1 & G2 & G1 & G2 & G1 & G2 & G1 & G2 \\
\hline 0.00 & 0.450 & 0.431 & 0.450 & 0.430 & 0.450 & 0.430 & 0.4500 & 0.4300 & 0.450 & 0.430 \\
\hline 0.08 & 0.400 & 0.380 & 0.450 & 0.430 & 0.450 & 0.430 & 0.4550 & 0.4300 & 0.450 & 0.430 \\
\hline 0.17 & 0.410 & 0.370 & 0.450 & 0.430 & 0.450 & 0.430 & 0.4550 & 0.4300 & 0.450 & 0.428 \\
\hline 0.25 & 0.390 & 0.390 & 0.445 & 0.435 & 0.450 & 0.428 & 0.4500 & 0.4265 & 0.445 & 0.435 \\
\hline 0.33 & 0.380 & 0.380 & 0.445 & 0.435 & 0.450 & 0.428 & 0.4400 & 0.4000 & 0.445 & 0.435 \\
\hline 0.42 & 0.385 & 0.375 & 0.445 & 0.435 & 0.440 & 0.420 & 0.3200 & 0.2200 & 0.440 & 0.430 \\
\hline 0.50 & 0.390 & 0.370 & 0.442 & 0.435 & 0.440 & 0.420 & 0.2200 & 0.2100 & 0.440 & 0.420 \\
\hline 0.58 & 0.410 & 0.370 & 0.442 & 0.435 & 0.430 & 0.411 & 0.2112 & 0.1900 & 0.430 & 0.410 \\
\hline 0.67 & 0.410 & 0.370 & 0.435 & 0.425 & 0.430 & 0.411 & 0.2000 & 0.1900 & 0.430 & 0.410 \\
\hline 0.75 & 0.400 & 0.380 & 0.430 & 0.410 & 0.430 & 0.410 & 0.1900 & 0.1900 & 0.420 & 0.400 \\
\hline 0.83 & 0.355 & 0.345 & 0.430 & 0.410 & 0.430 & 0.410 & 0.1900 & 0.1700 & 0.420 & 0.400 \\
\hline 0.92 & 0.330 & 0.330 & 0.430 & 0.410 & 0.430 & 0.410 & 0.1875 & 0.1725 & 0.410 & 0.390 \\
\hline 1.00 & 0.315 & 0.305 & 0.430 & 0.410 & 0.415 & 0.405 & 0.1775 & 0.1625 & 0.410 & 0.390 \\
\hline 1.08 & 0.305 & 0.295 & 0.430 & 0.410 & 0.410 & 0.390 & 0.1775 & 0.1625 & 0.400 & 0.380 \\
\hline 1.17 & 0.280 & 0.280 & 0.428 & 0.410 & 0.400 & 0.382 & 0.1700 & 0.1600 & 0.400 & 0.380 \\
\hline 1.25 & 0.172 & 0.170 & 0.428 & 0.410 & 0.398 & 0.382 & 0.1700 & 0.1600 & 0.400 & 0.380 \\
\hline 1.33 & 0.134 & 0.130 & 0.428 & 0.410 & 0.390 & 0.380 & 0.1700 & 0.1550 & 0.395 & 0.385 \\
\hline 1.42 & 0.140 & 0.135 & 0.422 & 0.400 & 0.390 & 0.370 & 0.1700 & 0.1550 & 0.380 & 0.380 \\
\hline 1.50 & 0.120 & 0.120 & 0.422 & 0.400 & 0.390 & 0.370 & 0.1650 & 0.1400 & 0.370 & 0.370 \\
\hline 1.58 & 0.085 & 0.075 & 0.422 & 0.400 & 0.380 & 0.360 & 0.1600 & 0.1400 & 0.380 & 0.340 \\
\hline 1.67 & 0.040 & 0.040 & 0.420 & 0.400 & 0.350 & 0.330 & 0.1500 & 0.1315 & 0.300 & 0.280 \\
\hline 1.75 & 0.020 & 0.020 & 0.418 & 0.400 & 0.355 & 0.334 & 0.1500 & 0.1315 & 0.270 & 0.250 \\
\hline 1.83 & 0.020 & 0.020 & 0.350 & 0.330 & 0.190 & 0.150 & 0.1450 & 0.1315 & 0.270 & 0.250 \\
\hline 1.92 & 0.020 & 0.020 & 0.310 & 0.270 & 0.170 & 0.140 & 0.1300 & 0.1225 & 0.170 & 0.152 \\
\hline
\end{tabular}




\begin{tabular}{|c|c|c|c|c|c|c|c|c|c|c|}
\hline \multirow{2}{*}{$\begin{array}{l}\text { Time } \\
(\mathrm{hr})\end{array}$} & \multicolumn{2}{|c|}{$\mathrm{T}_{1}$} & \multicolumn{2}{|c|}{$\mathrm{T}_{2}$} & \multicolumn{2}{|c|}{$\mathrm{T}_{3}$} & \multicolumn{2}{|c|}{$\mathrm{T}_{4}$} & \multicolumn{2}{|c|}{$\mathrm{T}_{5}$} \\
\hline & G1 & G2 & G1 & G2 & G1 & G2 & G1 & G2 & G1 & G2 \\
\hline 2.00 & & & 0.300 & 0.260 & 0.130 & 0.110 & 0.1240 & 0.1200 & 0.158 & 0.140 \\
\hline 2.08 & & & 0.285 & 0.255 & 0.130 & 0.110 & 0.1115 & 0.1100 & 0.148 & 0.130 \\
\hline 2.17 & & & 0.268 & 0.232 & 0.115 & 0.100 & 0.1021 & 0.1000 & 0.132 & 0.131 \\
\hline 2.25 & & & 0.205 & 0.195 & 0.100 & 0.095 & 0.0900 & 0.0900 & 0.121 & 0.120 \\
\hline 2.33 & & & 0.185 & 0.175 & 0.080 & 0.078 & 0.0500 & 0.0500 & 0.111 & 0.110 \\
\hline 2.42 & & & 0.170 & 0.165 & 0.060 & 0.058 & 0.0500 & 0.0500 & 0.080 & 0.080 \\
\hline 2.50 & & & 0.150 & 0.145 & 0.060 & 0.058 & & & 0.080 & 0.080 \\
\hline 2.58 & & & 0.110 & 0.108 & 0.040 & 0.040 & & & 0.080 & 0.080 \\
\hline 2.67 & & & 0.100 & 0.100 & 0.020 & 0.020 & & & & \\
\hline 2.75 & & & 0.050 & 0.050 & 0.020 & 0.020 & & & & \\
\hline 2.83 & & & 0.050 & 0.050 & 0.020 & 0.020 & & & & \\
\hline 2.92 & & & 0.050 & 0.050 & 0.020 & 0.020 & & & & \\
\hline 3.00 & & & & & 0.020 & 0.020 & & & & \\
\hline 3.08 & & & & & 0.020 & 0.020 & & & & \\
\hline 3.17 & & & & & 0.020 & 0.020 & & & & \\
\hline 3.25 & & & & & 0.020 & 0.020 & & & & \\
\hline
\end{tabular}

Where: $\mathrm{V} / \mathrm{H}$ is the vertical/horizontal length, $d_{50}$ is the size of soil median, $C$ is the soil cohesion, $\varphi$ is angle of friction, $C T$ is the headcut migration coefficient depends on materials, $Q$ is the water flow, $\omega$ is the water content, $\rho$ is the compacted density, $\rho_{d}$ is the dry density, and T is experiment or laboratory test.

$$
F_{r m}^{2}=\frac{U_{m}^{2}\left(B_{w t}\right) m}{g d_{m} B_{w d} \operatorname{Cas} \beta},
$$

where: $U_{m}$ is the cross-sectional averaged normal flow velocity, $B_{w t}$ is the breach width at the dam top, $B_{w d}$ is the breach width at the downstream slope, and $g$ is the gravitational acceleration. In this study, the preliminary breach was considered to be rectangular on the downstream slope; $U_{m}$ and $d_{m}$ were calculated as follows:

$U_{m}=C \sqrt{R_{m} \sin \beta}=C \sqrt{H \sin \beta}$ for $X \geq l_{m}$,

$d_{m}=\frac{Q_{b}}{U_{m} B_{w d}}$ for $X \geq l_{m}$

where: $R_{m}$ is the hydraulic radius of breach, $Q_{b}$ denotes breach flow, $R_{m}=H=Z_{w}-Z_{b}$, with $Z_{w}$ being water level in the reservoir, $Z_{b}$ representing the elevation of breach bottom, and $C$ is Chezy coefficient.

The Chezy coefficient was calculated by the Manning formula:

$C=\frac{1}{n} R_{m}^{1 / 6}$,

where: $n$ is the Manning's roughness coefficient. The Manning's $n$ is related sediment and computed by: $n=\frac{d_{50}^{1 / 6}}{A_{n}}$.

Where: $d_{50}$ is the median size (in meter), $A_{n}$ is an empirical coefficient. An approximately 16 laboratory cases and 12 for the field cases [15].

\section{Overflow discharge}

The overtopping flow at the breach was calculated using a broad-crested weir equation:

$Q_{b}=K_{s m}\left(C_{1} B_{w b} H^{1.5}+C_{2} S H^{2.5}\right)$.

Where: $B_{w b}$ is the bottom width of the breach, $S$ is the side slope of the breach, $\mathrm{C}_{1}$ is $1.7, \mathrm{C}_{2}$ is 1.3 [18], and $K_{s m}$ is the submergence correction for tailwater effects on weir outflow. $K_{s m}$ is the determined with the empirical relationship used by Fread [19] and Singh [18].

Flow velocity based on breach discharge was computed by:

$V=\frac{Q_{b}}{A_{b}}$.

Where: $V$ is breach flow velocity and $A_{b}$ is the breach cross-sectional area. 


\subsubsection{Determination morphological characteristics of} breach processes

Breach morphology change

According to $\mathrm{Wu}$ [12], the volume change at each reach of the breach was calculated by:

$\Delta V_{b}=\Delta E A_{e}$.

Where: $A_{e}$ is the erodible surface area of the breach channel under water, $\Delta E$ is the erosion thickness at the bed and side walls of the breach for a given time step $\Delta t$.

The actual erosion thickness was calculated at each time step as follows:

$\Delta Z_{b=} \frac{\Delta V_{b}}{A_{e, t o t}}$.

Where: $A_{e, t o t}$ is the total erodible surface area of the breach channel including both the portion below and above the water.

Thus, the relationship between $\Delta B$ and $\Delta Z_{b}$ (Fig. 4):

$\Delta B=\frac{n_{l o c} \Delta Z_{b}}{\sin \beta}$.

Where: $\Delta B$ is the horizontal expansion values at each time step, $\Delta Z_{b}$ is the vertical undercutting value at each time step, $n_{l o c}$ is indicator for breach location $\left(n_{l o c}=1\right.$ for one-sided breach and 2 for breach located at the middle of dam length) [15], and $\beta$ is the breach side slope angle with respect to horizontal.

\subsubsection{Structural failure}

Based on our laboratory experimental tests the failure mechanism considered was from the side slope stability analysis by assuming the failure plane has an angle of $\alpha$ and intersects the slope at the bank toe. In this experiment, it was considered that the collapsed block is washed away rapidly. The slope stability failure requires:

$F_{D} \leq F_{R}$

where: $F D$ is the driving force for the slope failure, and $F R$ is the resultant resistance force including cohesion and friction forces (Fig. 5).The value of $F D$ and $F R$ are obtained by the following expressions:

$$
\begin{aligned}
& F_{D}=\frac{1}{2} \gamma H_{s}\left(\frac{1}{\tan \alpha}-\frac{1}{\tan \beta}\right) \sin \alpha . \\
& F_{R}=\frac{1}{2} \gamma_{s} H_{s}^{2}\left(\frac{1}{\tan \alpha}-\frac{1}{\tan \beta}\right) \cos \alpha \tan \varphi+\frac{C H_{s}}{\sin \alpha} .
\end{aligned}
$$

Where: $H_{s}$ is the slope height, $\varphi$ is the frictional angle, $\gamma_{s}$ is the bulk specific weight, and $C$ is the soil cohesion.

\subsubsection{Flowchart for the analysis}

The iterative strategy for time steps was adopted to calculate breach discharge, breach flow velocity, breach advancement, breach depth at each time step. The technique used for the cohesive embankment dam breach due to overtopping is described as follows (Fig. 6):

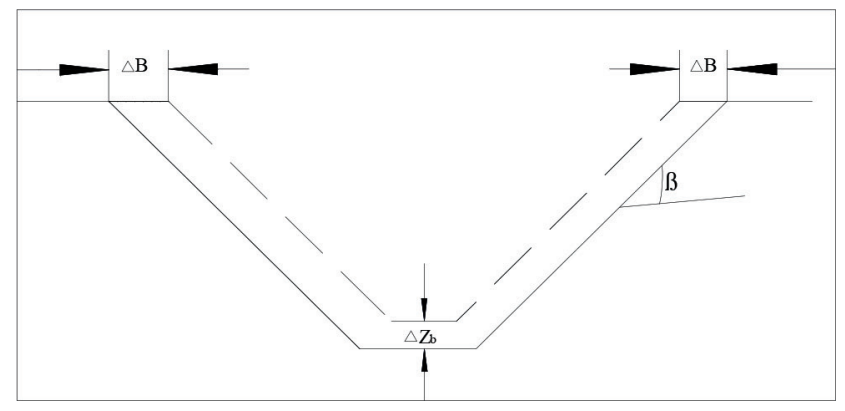

Fig. 4 Dam breach development

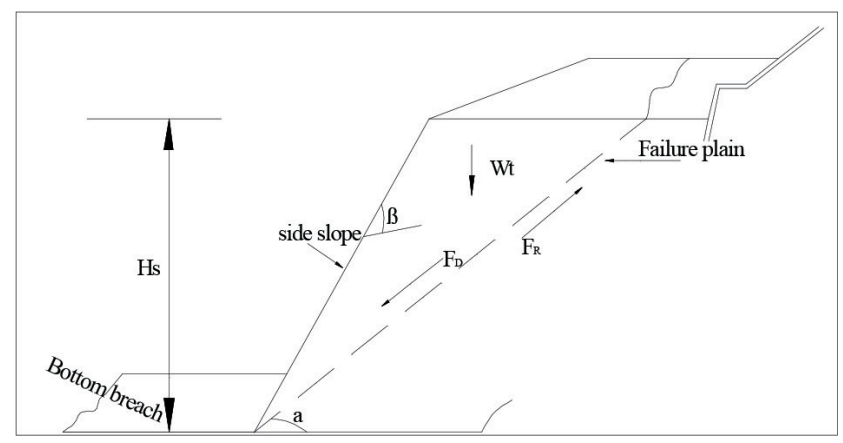

Fig. 5 Breach stability analysis of side slope

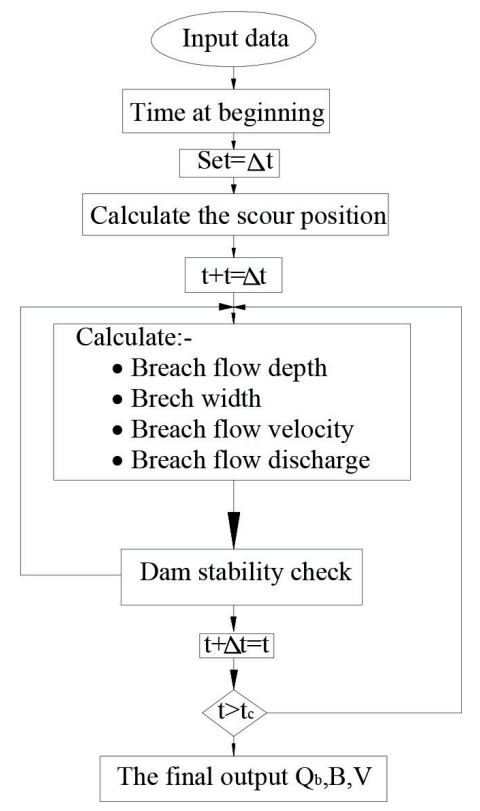

Fig. 6 Flow charts for the analysis 


\subsubsection{Model performance}

The overall performance of the model which mentioned above is assessed by comparing the observed and calculated peak discharges, breach widths, breach flow velocities and time to peak discharge using the measured and calculated data. To further quantify the model performance, Root Mean Square Error (RMSE) which measure the standard deviation of the residual i.e. the difference between the model predictions and the true values, RMSE, is defined as:

$$
R M S E=\sqrt{\frac{1}{N} \sum_{i=N}^{N}(A-F)^{2}} .
$$

Where: $A$ is actual or observed data $F$ is forecasted or calculated data and $N$ is number of data points.

\section{Result and discussion}

\subsection{Results}

Evaluation of the embankment dam breach profile was determined from the photographs and videos. For tests $\mathrm{T}_{1}$, $\mathrm{T}_{2}, \mathrm{~T}_{3}, \mathrm{~T}_{4}$ and $\mathrm{T}_{5}$ (i.e. the test with clay and sand-clay soil), it was observed that initial scouring position near to the toe of embankment dam when the embankment was overflowed, for all tests, (e.g. Fig. 7(b)). This erosion with scouring occurs at the lower part of the slope than at the upper part, inducing a steepening of the slope and widening the breach channel in time (e.g. Fig. 7). Next to the toe of the embankment, the transition area between the embankment dam downstream slope and the crest was the second place exposed to faster and earlier erosion. Erosion at the embankment crest was relatively slow, due to erosion resistance of the soil materials and degree of compaction. However, this erosion lowered the height of the embankment and widened breach channel, and increased the breach flow rate eventually, which in turn facilitate the breach erosion process. Generally, for the five small-scale tests from the observed breaching development might be classified into five stages:

Stage 1 (Figs. 7(a) , 7(b), Figs. 8(a) and 8(b); Tables 2-7): The passage of flow over the unbroken embankment, the initiation of erosion and appearance of rills was observed. At the downstream toe and downstream slope, the appearance of initial headcut and scouring hole of breach channel was observed. Flowing down attaching to the down slope surface with less strong scour potential, at the beginning the average measured results of $\mathrm{Q}, \mathrm{V}$, and $\mathrm{H}$ have lower values with $0.00034 \mathrm{~m}^{3} / \mathrm{s}, 0.11 \mathrm{~m} / \mathrm{s}$ and 0.0061 $\mathrm{m}$ respectively.

Stage 2 (Fig. 7(c) and Fig. 8(c); Tables 2-7): During the transition from stage 1 to 2 , for all test, the change between the embankment crest and the downstream slope sometimes eroded into a rounded angle, when $\mathrm{Q}$ and $\mathrm{V}$ rapidly increases in average from 0.00034 to $0.0008 \mathrm{~m}^{3} / \mathrm{se}$ and $0.11 \mathrm{~m} / \mathrm{s}$ to $0.197 \mathrm{~m} / \mathrm{s}$ respectively. Still, the breach flow did not fully flee away from the downstream slope at the top, instead it rushed down along the slope and detached from the slope at a certain lower point (that is the approximated value on average at $0.6 \mathrm{~m}$ from the crest of dam) and imposed towards the bases, however, breach channel was increased in depth and width to $0.055 \mathrm{~m}$ and $0.35 \mathrm{~m}$ respectively. The steepened downstream slope of the embankment evolved gradually into a headcut. A series of cascading

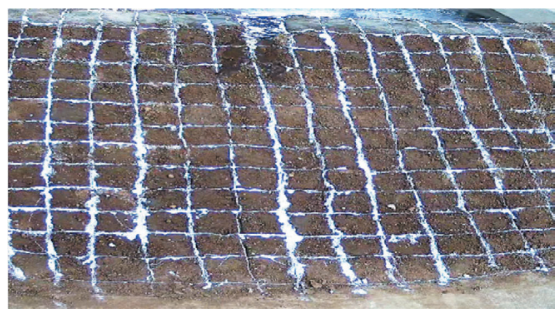

(a)

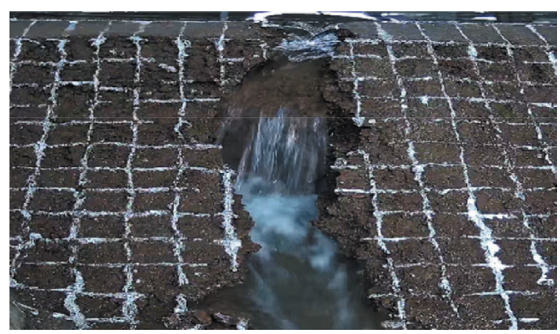

(d)

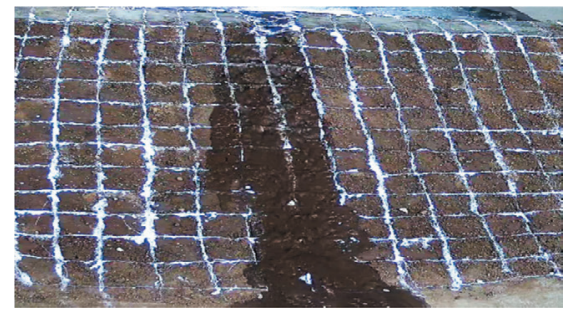

(b)

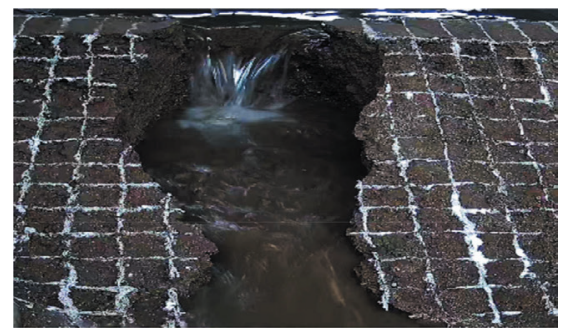

(e)

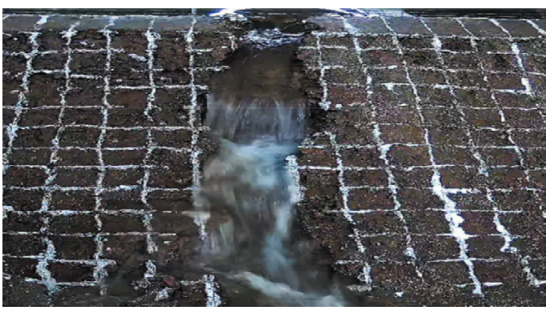

(c)

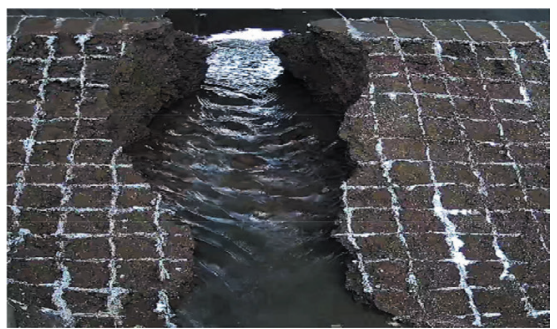

(f)

Fig. 7 Homogenous cohesive dam breaching process during overtopping 


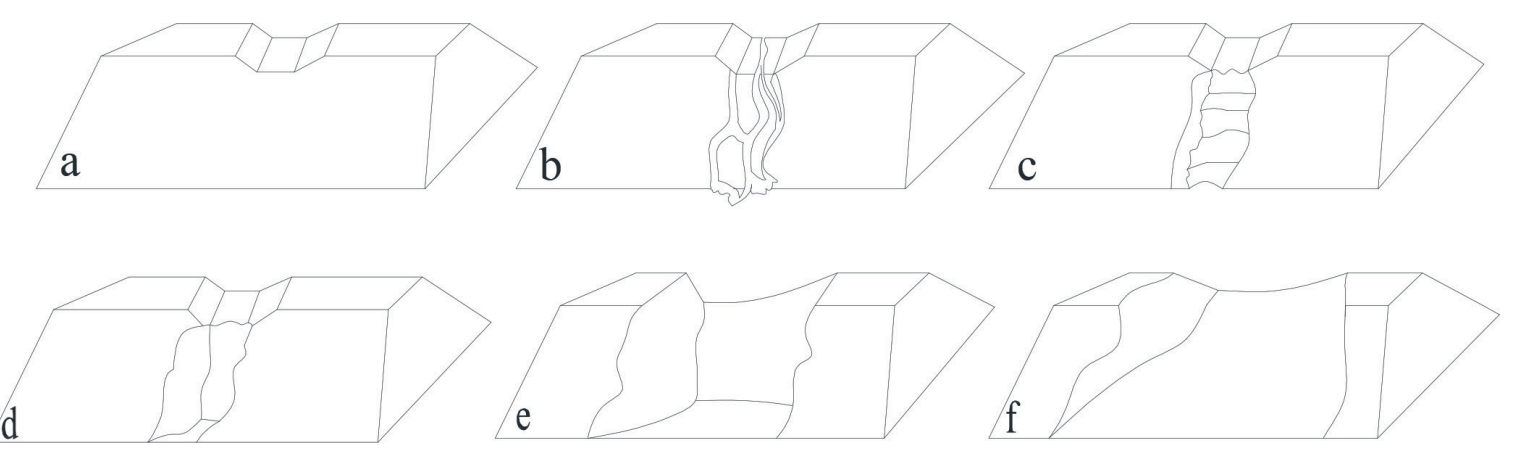

Fig. 8 Observed schematic diagrams for cohesive dam breaching process during overtopping

overfalls were observed due to retrograde erosion of the downstream slope at a constant angle of approximately $90^{\circ}$, thus, resulting in an increases of breaching width and depth (i.e. increased to $0.42 \mathrm{~m}$ and $0.065 \mathrm{~m}$ respectively), concurrently decrease of the crest length to $1.43 \mathrm{~m}$ while the breach side-slope remained vertical. At the end of this stage, surface erosion was observed and the breach flow flee away from the downstream slope started to be observed.

Stage 3 (Fig. 7(d) and Fig. 8(d); Tables 2-7): The cascade changed into a single upstream eroding headcut, consequently, on average the crest elevation of the dam was lowered to $0.33 \mathrm{~m}$ after formation of the head cut, the flow shear erosion. The breach flow imposed like a waterfall (jet) onto the downstream breach bottom, impinging considerable erosive forces on the toe of the slope also on the left and right bottom of breached channel. Strong scour of the toe of the slope (i.e. headcut undermining, because of at this point in average Q rise to $0.0297 \mathrm{~m}^{3} / \mathrm{s}, \mathrm{V}$ to 0.5354 $\mathrm{m} / \mathrm{se}$ and $\mathrm{H}$ to $0.0893 \mathrm{~m}$ ) was observed due to the waterfall pressure, which leads to soil slope mass failure in all the five tests. A variation of side-slope angle due to lateral and vertical soil mechanical slope mass failure started to be observed thereby increasing the breach depth and width to $0.62 \mathrm{~m}$ and $0.12 \mathrm{~m}$ respectively.

Stage 4 (Fig. 7(e), Fig. 8(e), Tables 2-7): All the five tests with cohesive soil (i.e. tests $\mathrm{T}_{1}, \mathrm{~T}_{2}, \mathrm{~T}_{3}, \mathrm{~T}_{4}$ and $\mathrm{T}_{5}$ ), waterfall and breach flow flee away from the downstream slope was continue but a single upstream eroding headcut was shaped or converted to wedge form. Soil mechanical slope mass failure occurrence was continued distinctly from the headcut, however, irregular. When this slope mass failure occurred, the soil which eroded from the headcut could be a large chunk, including laterally, followed by an immediate increase of the breach flow (i.e. averagely from $0.0297 \mathrm{~m}^{3} / \mathrm{s}$ to $0.0672 \mathrm{~m}^{3} / \mathrm{s}$ ). It was also observed that in all test cases the occurrence of headcut slope mass failure happened together with by occurrence of $\operatorname{crack}(\mathrm{s})$ on the top of the headcut.
In traditional soil mechanics theory soil tensile strength is often not taken into account, thus cracking may occur due to the nature of construction material and degree of compaction. This might indicate that the existence of weak tensile stress in the soil is needed to be considered when dealing with compacted cohesive embankment breach erosion. Therefore, side-slope angle and sidewall bottom erosion results into mass failures. Subsequently, the breach enlargement or breach growth continued vertically and laterally. Before the beginning of stage 5 the flow discharge, velocity and depth starts to drop i.e. on average reduced to 0.02615 $\mathrm{m}^{3} / \mathrm{s}, 0.387 \mathrm{~m} / \mathrm{s}$ and $0.0601 \mathrm{~m}$ respectively.

Stage 5 (Fig. 7(f), Fig. 8(f), Tables 2-7): At final stage, the measured average value of $\mathrm{Q}, \mathrm{V}$ and $\mathrm{H}$ were reduced to $0.0207 \mathrm{~m}^{3} / \mathrm{se}, \mathrm{V}$ to $0.202 \mathrm{~m} / \mathrm{s}$ and $0.038 \mathrm{~m}$ respectively. That observed wedge-shaped at stage 4 was totally removed and full breach channel was observed. The soil mechanical slope mass failure from the headcut was continued from the laterals until the water flow level reduced and the breach growth continued to reach full width. At the final stage, the breach erosion ceased while water elevation in the reservoir was at the same level as the breach bottom.

\subsection{Discussion}

The initial scour position, the breach flow accelerates from $X=0$ at the crest to $X=1_{m}$ where it reaches the normal flow velocity. In Table 8 and Fig. 9 , it is computed by hydraulic method equation for the five consecutive serious embankment dams model, the results are not approximate the true position. However, observed results from all the tests are indicate at the downstream toe of the dam. The limitation of this equation is not appropriate for the small scale dam models or/and dam without enough slope.

The breaching parameters for the laboratory tests $T_{1}$, $\mathrm{T}_{2}, \mathrm{~T}_{3}, \mathrm{~T}_{4}$ and $\mathrm{T}_{5}$ besides Figs. 10-14 shows that the test results of the three parameters including time, compare the observed and calculated breach flow hydrographs, breach 
Table 2 Maximum and minimum value of observed data at stage - 1

\begin{tabular}{|c|c|c|c|c|c|c|c|c|c|c|}
\hline \multicolumn{11}{|c|}{ Observed data at Stage - 1} \\
\hline & \multicolumn{2}{|c|}{$t(\mathrm{hr})$} & \multicolumn{2}{|c|}{$Q\left(\mathrm{~m}^{3} / \mathrm{s}\right)$} & \multicolumn{2}{|c|}{$V(\mathrm{~m} / \mathrm{s})$} & \multicolumn{2}{|c|}{$B_{w}(\mathrm{~m})$} & \multicolumn{2}{|c|}{$h(\mathrm{~m})$} \\
\hline & Min. value & Max. value & Min. value & Max. value & Min. value & Max. value & Min. value & Max. value & Min. value & Max. value \\
\hline $\mathrm{T}_{1}$ & 0.00 & 0.083 & 0.00 & 0.0009 & 0.000 & 0.453 & 0.2 & 0.2 & 0.00 & 0.007 \\
\hline $\mathrm{T}_{2}$ & 0.00 & 0.083 & 0.00 & 0.000063 & 0.000 & 0.031 & 0.2 & 0.20 & 0.00 & 0.0070 \\
\hline $\mathrm{T}_{3}$ & 0.00 & 0.083 & 0.00 & 0.0000 & 0.000 & 0.000 & 0.2 & 0.20 & 0.00 & 0.0016 \\
\hline $\mathrm{T}_{4}$ & 0.00 & 0.083 & 0.00 & 0.00011 & 0.000 & 0.007 & 0.2 & 0.20 & 0.00 & 0.0048 \\
\hline $\mathrm{T}_{5}$ & 0.00 & 0.083 & 0.00 & 0.00062 & 0.000 & 0.059 & 0.2 & 0.20 & 0.00 & 0.0100 \\
\hline
\end{tabular}

Table 3 Maximum and minimum value of observed data at stage - 2

\begin{tabular}{|c|c|c|c|c|c|c|c|c|c|c|}
\hline \multicolumn{11}{|c|}{ Observed data at Stage - 2} \\
\hline & \multicolumn{2}{|c|}{$t(\mathrm{hr})$} & \multicolumn{2}{|c|}{$Q\left(\mathrm{~m}^{3} / \mathrm{s}\right)$} & \multicolumn{2}{|c|}{$V(\mathrm{~m} / \mathrm{s})$} & \multicolumn{2}{|c|}{$B_{w}(\mathrm{~m})$} & \multicolumn{2}{|c|}{$h(\mathrm{~m})$} \\
\hline & Min. value & Max. value & Min. value & Max. value & Min. value & Max. value & Min. value & Max. value & Min. value & Max. value \\
\hline $\mathrm{T}_{1}$ & 0.0833 & 0.5833 & 0.0008 & 0.0089 & 0.6070 & 0.9370 & 0.20 & 0.59 & 0.0050 & 0.031 \\
\hline $\mathrm{T}_{2}$ & 0.0833 & 0.6700 & 0.0001 & 0.0060 & 0.0500 & 0.1510 & 0.25 & 0.42 & 0.0112 & 0.057 \\
\hline $\mathrm{T}_{3}$ & 0.0800 & 0.1700 & 0.000002 & 0.000002 & 0.0010 & 0.0010 & 0.20 & 0.20 & 0.0074 & 0.007 \\
\hline $\mathrm{T}_{4}$ & 0.0833 & 0.2500 & 0.000599 & 0.0090 & 0.0670 & 0.5507 & 0.20 & 0.30 & 0.0447 & 0.067 \\
\hline $\mathrm{T}_{5}$ & 0.0800 & 0.3300 & 0.00246 & 0.0064 & 0.2620 & 0.3720 & 0.20 & 0.23 & 0.0447 & 0.057 \\
\hline
\end{tabular}

Table 4 Maximum and minimum value of observed data at stage - 3

\begin{tabular}{|c|c|c|c|c|c|c|c|c|c|c|}
\hline \multicolumn{11}{|c|}{ Observed data at Stage - 3} \\
\hline & \multicolumn{2}{|c|}{$t(\mathrm{hr})$} & \multicolumn{2}{|c|}{$Q\left(\mathrm{~m}^{3} / \mathrm{s}\right)$} & \multicolumn{2}{|c|}{$V(\mathrm{~m} / \mathrm{s})$} & \multicolumn{2}{|c|}{$B_{w}(\mathrm{~m})$} & \multicolumn{2}{|c|}{$h(\mathrm{~m})$} \\
\hline & Min. value & Max. value & Min. value & Max. value & Min. value & Max. value & Min. value & Max. value & Min. value & Max. value \\
\hline $\mathrm{T}_{1}$ & 0.583 & 0.917 & 0.0158 & 0.0867 & 0.6410 & 1.217 & 0.62 & 0.80 & 0.040 & 0.1020 \\
\hline $\mathrm{T}_{2}$ & 0.670 & 1.920 & 0.0001 & 0.0060 & 0.0510 & 0.220 & 0.50 & 0.70 & 0.059 & 0.1276 \\
\hline $\mathrm{T}_{3}$ & 0.170 & 0.750 & 0.000002 & 0.0006 & 0.0010 & 0.036 & 0.20 & 0.28 & 0.007 & 0.0594 \\
\hline $\mathrm{T}_{4}$ & 0.250 & 0.500 & 0.0089 & 0.0436 & 0.4417 & 0.712 & 0.30 & 0.90 & 0.067 & 0.0882 \\
\hline $\mathrm{T}_{5}$ & 0.330 & 0.830 & 0.0065 & 0.0116 & 0.3620 & 0.492 & 0.30 & 0.40 & 0.049 & 0.0694 \\
\hline
\end{tabular}

Table 5 Maximum and minimum value of observed data at stage - 4

\begin{tabular}{|c|c|c|c|c|c|c|c|c|c|c|}
\hline \multicolumn{11}{|c|}{ Observed data at Stage - 4} \\
\hline & \multicolumn{2}{|c|}{$t(\mathrm{hr})$} & \multicolumn{2}{|c|}{$Q\left(\mathrm{~m}^{3} / \mathrm{s}\right)$} & \multicolumn{2}{|c|}{$V(\mathrm{~m} / \mathrm{s})$} & \multicolumn{2}{|c|}{$B_{w}(\mathrm{~m})$} & \multicolumn{2}{|c|}{$h(\mathrm{~m})$} \\
\hline & Min. value & Max. value & Min. value & Max. value & Min. value & Max. value & Min. value & Max. value & Min. value & Max. value \\
\hline $\mathrm{T}_{1}$ & 0.9167 & 1.5830 & 0.1886 & 0.2815 & 0.1100 & 0.7890 & 1.03 & 1.25 & 0.0171 & 0.1047 \\
\hline $\mathrm{T}_{2}$ & 1.9200 & 2.6667 & 0.0001 & 0.0027 & 0.090 & 0.0473 & 0.70 & 1.04 & 0.0400 & 0.0682 \\
\hline $\mathrm{T}_{3}$ & 0.7500 & 2.1667 & 0.0007 & 0.00437 & 0.0011 & 0.1980 & 0.30 & 0.80 & 0.0127 & 0.0788 \\
\hline $\mathrm{T}_{4}$ & 0.5000 & 2.2500 & 0.01343 & 0.05652 & 0.2074 & 0.7473 & 0.90 & 1.30 & 0.0229 & 0.0947 \\
\hline $\mathrm{T}_{5}$ & 0.8300 & 1.5800 & 0.00660 & 0.01756 & 0.3340 & 0.5560 & 0.40 & 0.50 & 0.0494 & 0.0741 \\
\hline
\end{tabular}

Table 6 Maximum and minimum value of observed data at stage -5

\begin{tabular}{|c|c|c|c|c|c|c|c|c|c|c|}
\hline \multicolumn{11}{|c|}{ Observed data at Stage - 5} \\
\hline & \multicolumn{2}{|c|}{$t(\mathrm{hr})$} & \multicolumn{2}{|c|}{$Q\left(\mathrm{~m}^{3} / \mathrm{s}\right)$} & \multicolumn{2}{|c|}{$V(\mathrm{~m} / \mathrm{s})$} & \multicolumn{2}{|c|}{$B_{w}(\mathrm{~m})$} & \multicolumn{2}{|c|}{$h(\mathrm{~m})$} \\
\hline & Min. value & Max. value & Min. value & Max. value & Min. value & Max. value & Min. value & Max. value & Min. value & Max. value \\
\hline $\mathrm{T}_{1}$ & 1.583 & 1.833 & 0.0053 & 0.0063 & 0.150 & 0.210 & 1.25 & 1.28 & 0.020 & 0.020 \\
\hline $\mathrm{T}_{2}$ & 2.667 & 2.917 & 0.0001 & 0.0020 & 0.014 & 0.159 & 1.20 & 1.20 & 0.030 & 0.040 \\
\hline $\mathrm{T}_{3}$ & 2.167 & 3.250 & 0.0001 & 0.0011 & 0.012 & 0.120 & 1.00 & 1.20 & 0.005 & 0.018 \\
\hline $\mathrm{T}_{4}$ & 2.250 & 2.420 & 0.0150 & 0.0150 & 0.136 & 0.136 & 1.30 & 1.30 & 0.045 & 0.085 \\
\hline $\mathrm{T}_{5}$ & 1.580 & 2.580 & 0.0134 & 0.0455 & 0.288 & 0.794 & 0.50 & 1.00 & 0.044 & 0.0770 \\
\hline
\end{tabular}


Table 7 The average percentage of root-mean - square-errs (RMSE) at each stage of breach process

\begin{tabular}{cccccccccccccccccccccccc}
\hline & \multicolumn{3}{c}{ MRES at Stage - } & \multicolumn{3}{c}{ MRES at Stage - } & \multicolumn{3}{c}{ MRES at Stage -3 } & \multicolumn{3}{c}{ MRES at Stage - 4} \\
& $Q(\%)$ & $V(\%)$ & $B_{w}(\%)$ & $Q(\%)$ & $V(\%)$ & $B_{w}(\%)$ & $Q(\%)$ & $V(\%)$ & $B_{w}(\%)$ & $Q(\%)$ & $V(\%)$ & $B_{w}(\%)$ & $Q(\%)$ & $V(\%)$ & $B_{w}(\%)$ \\
\hline $\mathrm{T}_{1}$ & 0.01 & 7.38 & 0.92 & 0.14 & 16.26 & 29.00 & 1.81 & 27.74 & 40.75 & 0.02 & 0.16 & 24.55 & 16.22 & 0.00 & 31.05 \\
$\mathrm{~T}_{2}$ & 0.00 & 1.33 & 1.33 & 0.18 & 6.60 & 11.18 & 0.23 & 6.26 & 9.84 & 0.10 & 11.60 & 15.67 & 0.10 & 7.87 & 10.00 \\
$\mathrm{~T}_{3}$ & 0.00 & 0.00 & 0.00 & 0.00 & 1.41 & 2.03 & 0.02 & 1.41 & 1.93 & 0.07 & 6.76 & 8.60 & 0.03 & 3.22 & 12.78 \\
$\mathrm{~T}_{4}$ & 0.29 & 2.67 & 0.75 & 0.22 & 22.54 & 28.88 & 0.16 & 13.03 & 29.89 & 1.61 & 12.53 & 9.11 & 2.49 & 29.15 & 0.00 \\
$\mathrm{~T}_{5}$ & 0.02 & 2.34 & 0.00 & 0.14 & 13.08 & 5.27 & 0.14 & 7.29 & 9.17 & 0.19 & 6.87 & 19.39 & 0.81 & 18.05 & 10.08 \\
\hline
\end{tabular}

Table 8 Initial scour position results

\begin{tabular}{|c|c|c|c|}
\hline Lab. test & $\begin{array}{l}\text { Computed scour } \\
\text { position, } l_{n}(\mathrm{~m})\end{array}$ & Observed scour position & Remark \\
\hline $\mathrm{T}_{1}$ & 23.73 & $\begin{array}{l}\text { at the downstream toe of } \\
\text { dam model }\end{array}$ & $1_{m}>X$ \\
\hline $\mathrm{T}_{2}$ & 7.12 & $\begin{array}{l}\text { at the downstream toe of } \\
\text { dam model }\end{array}$ & $1_{m}>X$ \\
\hline $\mathrm{T}_{3}$ & 13.46 & $\begin{array}{l}\text { at the downstream toe of } \\
\text { dam model }\end{array}$ & $1_{m}>X$ \\
\hline $\mathrm{T}_{4}$ & 16.95 & $\begin{array}{l}\text { at the downstream toe of } \\
\text { dam model }\end{array}$ & $1_{m}>X$ \\
\hline $\mathrm{T}_{5}$ & 4.40 & $\begin{array}{l}\text { at the downstream toe of } \\
\text { dam model }\end{array}$ & $1_{m}>X$ \\
\hline
\end{tabular}

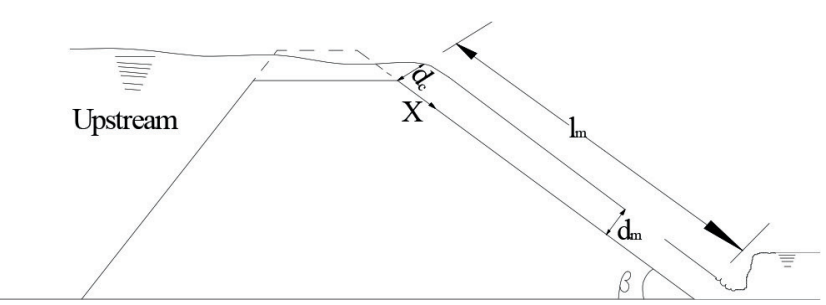

Fig. 9 Cross-sectional sketch of over intial breach postion at stage -1 [17]

widths and velocities are varying with time for the experiment cases. In light of these results for the parameters from the experimental tests discussions are as follows:

The maximum results of observed and calculated peak discharges are in Table 9. In Fig. 10(a), the calculated time to peak discharge is earlier than the measured one. The agreement of measured and computed breach hydrographs are plausible. Fig. 11(a) displays the computed breach hydrograph is slimmer than the measured one, the peak breach flow is slightly overestimated by the model but the time to peak is well reproduced. In Fig. 12(a), the measured breach hydrograph well proportionated than the computed one and peak discharge has a very small difference but the time to peak discharge is equal and well replicated. Fig. 13(a) shows that the measured and computed hydrographs are well proportionated, the peak discharge computed by the model is greater than the measured one, then the measured time to peak discharge is earlier than observed one and the time to peak is reasonable but as compared to the other is not well-replicated. Fig. 14(a) displays that both calculated and measured breach hydrographs are well-proportioned the computed peak breach discharge is underestimated by the model but the measured time earlier than the computed one and the time to peak is fairly replicated. Further, considering Table 9, the coputed peak breach flow discharge laboratory test $\mathrm{T}_{1}$ is $28.2 \%$ smaller than the measured one, for $\mathrm{T}_{2}$ its $3 \%$ larger than the measured data, for $\mathrm{T}_{3}$ it's $20.5 \%$ greater than the measured one, $\mathrm{T}_{4}$ it's $20.34 \%$ bigger than the computed data and $\mathrm{T}_{5}$ its $15.56 \%$ less than the computed one. Simultaneously, the time to peak discharge for experiment $T_{1}$ is $0.08 \mathrm{hr}$ later, for $\mathrm{T}_{2}$ its the same as the measured one, and for $\mathrm{T}_{3}$ it's $0.08 \mathrm{hr}$ earlier, for $\mathrm{T}_{4}$ its $0.67 \mathrm{hr}$ earlier and $\mathrm{T}_{5}$ its 0.16 hr earlier as compared to computed data.

As shown in Figs. 10(b), 11(b) and 12(b), the observed breach width increases very slowly at the beginning but significantly at the elapsed time of $0.33,0.25$ and $0.67 \mathrm{hr}$, respectively, when the headcut is migrates to the computed

Table 9 Results of overtopping laboratory test failure

\begin{tabular}{|c|c|c|c|c|c|c|c|c|}
\hline \multirow{2}{*}{ Lab. test } & \multicolumn{4}{|c|}{ Measured data } & \multicolumn{4}{|c|}{ Computed result } \\
\hline & $Q_{p}\left(\mathrm{~m}^{3} \mathrm{~s}^{-1}\right)$ & $B(\mathrm{~m})$ & $T_{p}(\mathrm{hr})$ & $V\left(\mathrm{~ms}^{-1}\right)$ & $Q_{p}\left(\mathrm{~m}^{3} \mathrm{~s}^{-1}\right)$ & $B(\mathrm{~m})$ & $T_{p}(\mathrm{hr})$ & $V\left(\mathrm{~ms}^{-1}\right)$ \\
\hline $\mathrm{T}_{1}$ & 0.0958 & 1.28 & 1.08 & 1.217 & 0.0688 & 1.60 & 1.00 & 0.953 \\
\hline $\mathrm{T}_{2}$ & 0.006 & 1.20 & 1.67 & 0.250 & 0.0062 & 1.30 & 1.67 & 0.220 \\
\hline $\mathrm{T}_{3}$ & 0.0044 & 1.20 & 1.75 & 0.198 & 0.0049 & 1.34 & 1.75 & 0.170 \\
\hline $\mathrm{T}_{4}$ & 0.0565 & 1.30 & 1.58 & 0.747 & 0.0679 & 1.30 & 2.17 & 0.552 \\
\hline $\mathrm{T}_{5}$ & 0.0450 & 1.00 & 2.17 & 0.790 & 0.0380 & 1.05 & 2.33 & 0.530 \\
\hline
\end{tabular}

Where: $Q_{p}$ is the peak breach flow, $B$ is the final top width, $T_{p}$ is the time to peak discharge, and $V$ is the maximum flow velocity. 


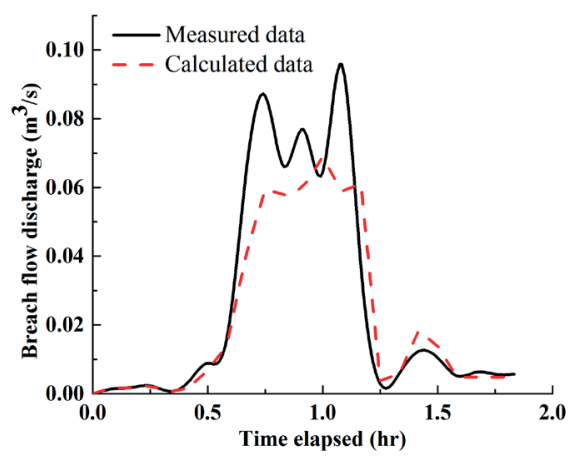

(a)

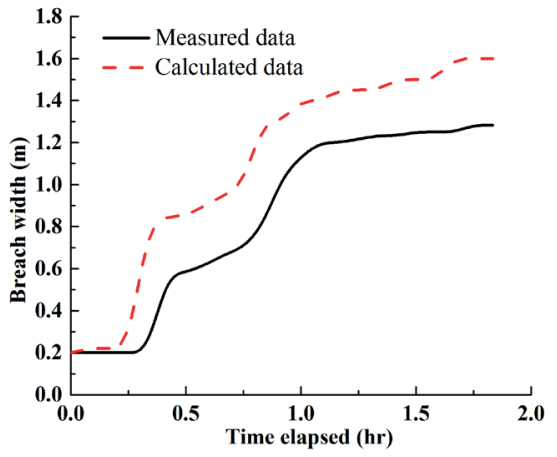

(b)

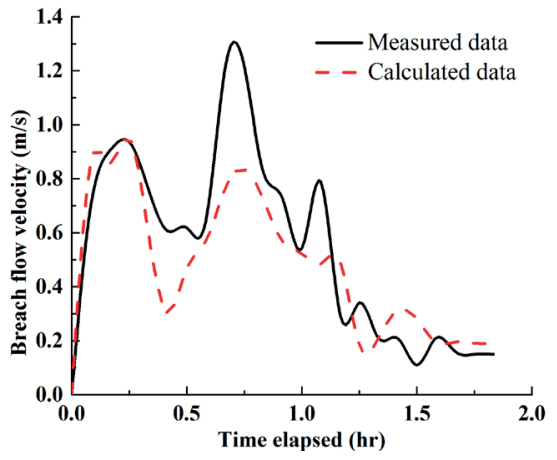

(c)

Fig. 10 (a) Breach flow discharge $T_{1}$, (b) Breach width development $T_{1}$, (c) Breach flow velocity $T_{1}$

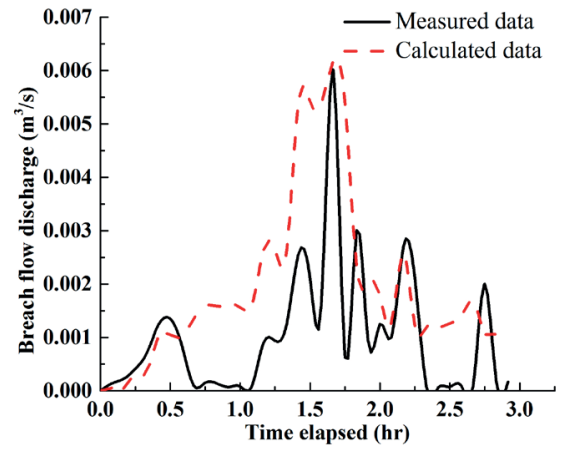

(a)

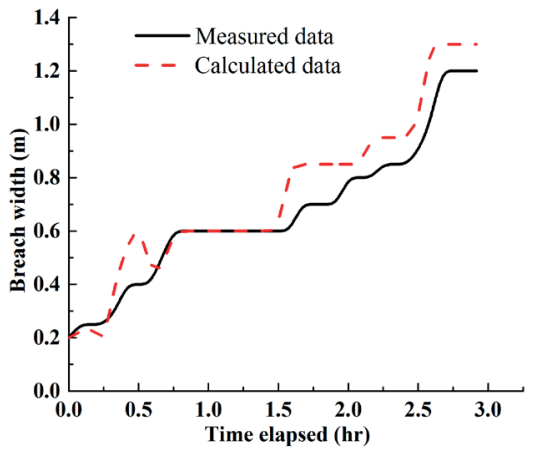

(b)

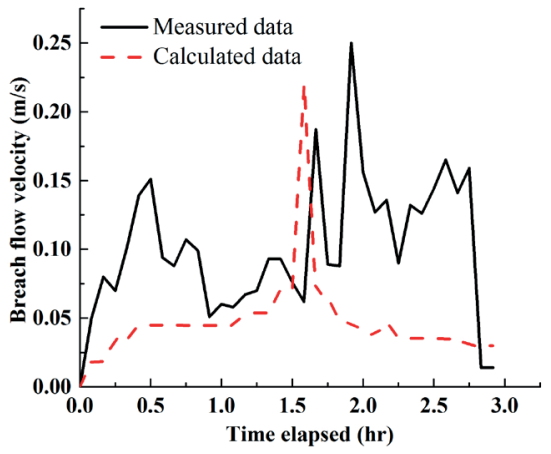

(c)

Fig. 11 (a) Breach flow discharge $T_{2}$, (b) Breach width development $T_{2}$, (c) Breach flow velocity $T_{2}$

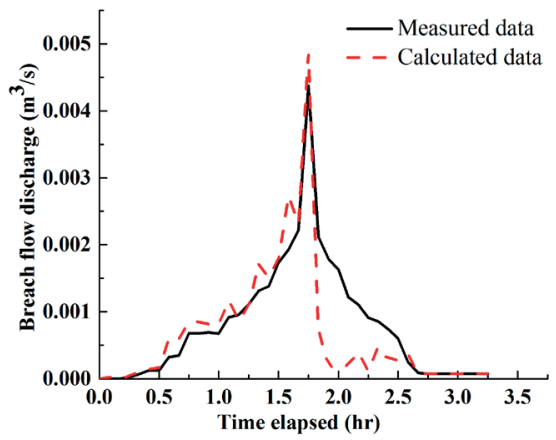

(a)

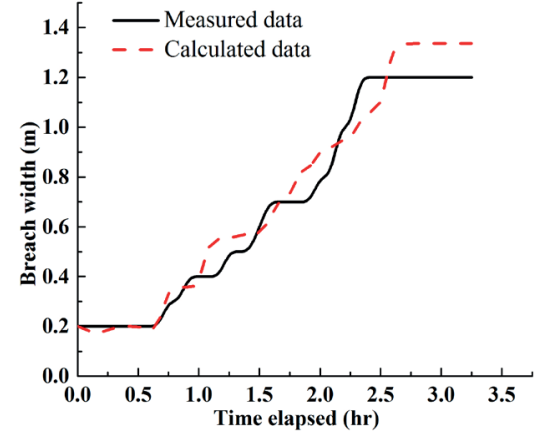

(b)

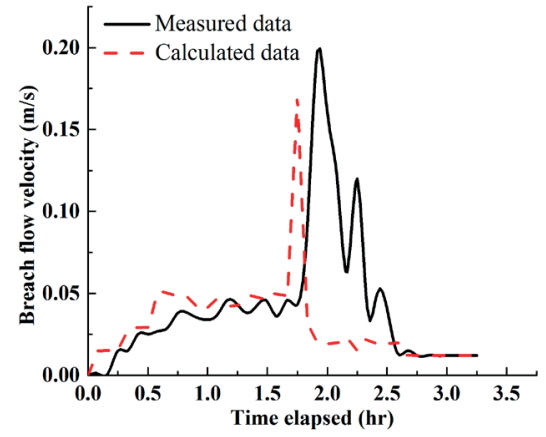

(c)

Fig. 12 (a) Breach flow discharge $T_{3}$, (b) Breach width development $T_{3}$, (c) Breach flow velocity $T_{3}$

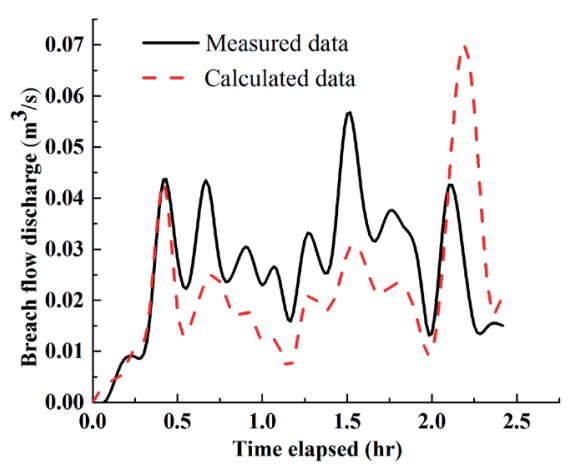

(a)

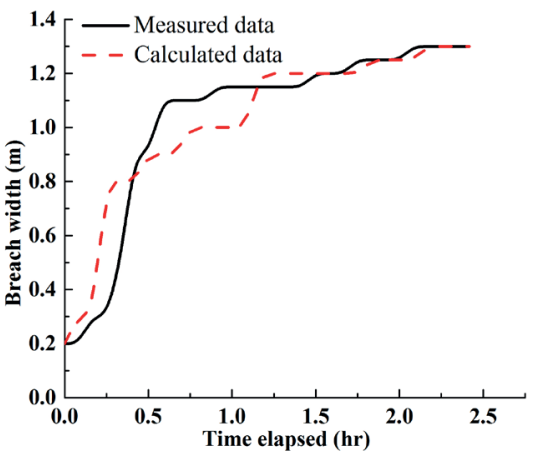

(b)

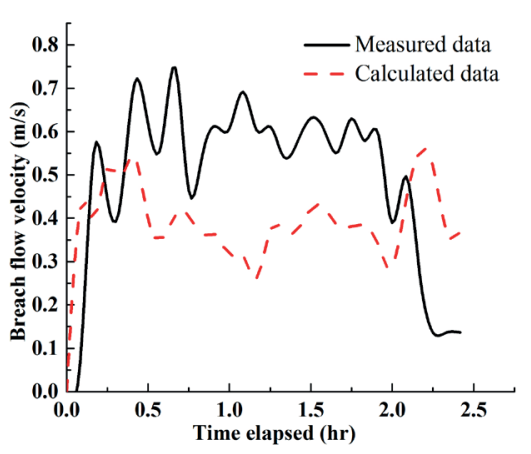

(c)

Fig. 13 (a) Breach flow discharge $\mathrm{T}_{4}$, (b) Breach width development $\mathrm{T}_{4}$, (c) Breach flow velocity $\mathrm{T}_{4}$ 


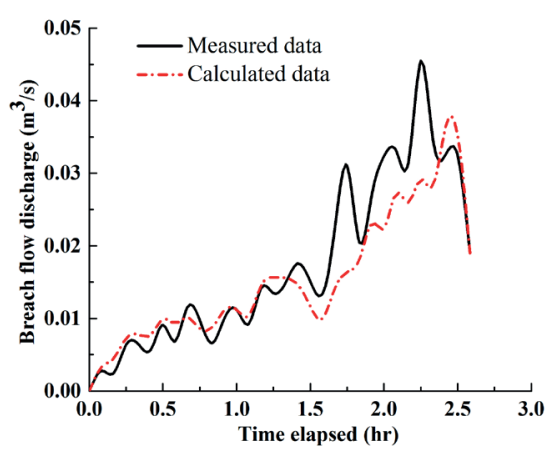

(a)

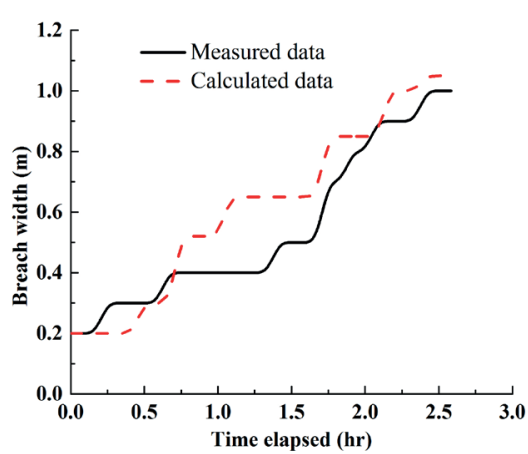

(b)

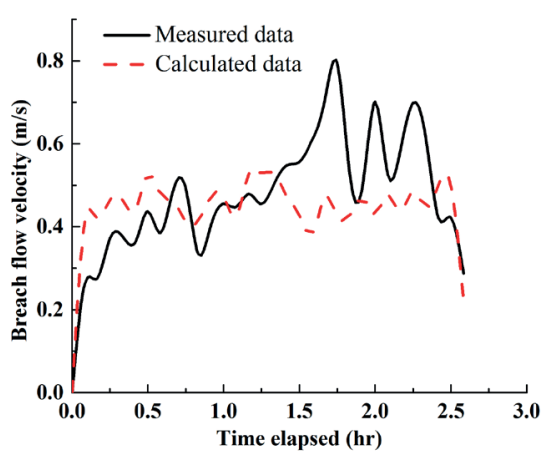

(c)

Fig. 14 (a) Breach flow discharge $\mathrm{T}_{5}$, (b) Breach width development $\mathrm{T}_{5}$, (c) Breach flow velocity $\mathrm{T}_{5}$

position, the cross-section of the downstream top corner of the dam. Likewise, Figs. 13(b) and 14(b) shows that the time taken at the beginning is $0.08 \mathrm{hr}$ for the measured breach width increments; 0.45 and $0.67 \mathrm{hr}$ respectively defining the time elapsed for headcut migrates to the computed location. The calculated breach width is very slow at the beginning with the elapsed time of $0.25,0.25$ and $0.33 \mathrm{hr}$ shown on Figs. 10(b), 12(b) and 14(b) respectively, this is due to plane top section that is washed away, and the wider downstream slope segment that becomes the breach channel (i.e. water force imposed on the downstream slope of the dam). However, Figs. 11(b) and 13(b) shows that the computed breaching start's immediately but time elapsed is $0.42 \mathrm{hr}$ when the headcut migrates to the measurement location. Nevertheless, Fig. 13(b) calculated breach width increase highly between 0.3 and $0.8 \mathrm{hr}$ and then both calculated and computed graphs are changed gradually, and their maximum results is the same, this might be due to the uniformity in degree of compaction of the dam.

In the breaching process, the velocity plays an important role in the erosion and scour of the embankment, deepening process of breach and the widening. For instance, when the shear stress imposed by the flow greater than the shear stress of embankment material erosion begins; with the increase in velocity, there is a corresponding increases in shear stress and velocity depends on the headwater conditions. In Figs. 10(c), 11(c), 12(c), 13(c) and 14(c), velocity in the breach channel is much larger than that of over the crest of pilot channel, and at the final stage of breach. This is due to the minimum flow depth at the beginning, and depletion of water in the reservoir and widening of breach channel while approaching end of the breach. Figs. 10(c), 12(c) and 14(c) shows that computed and measured velocity well-proportionate but Figs. 11(c) and 13(c) are not as compared to the others, this due to the version of breach width, breach shape and size. From Table 9, the maximum breach flow velocity for laboratory test $\mathrm{T}_{1}$ is $21.7 \%$ smaller than the measured one, for laboratory test $\mathrm{T}_{2}$ it is $12 \%$ less than the measured one, $\mathrm{T}_{3}$ it is $14.1 \%$ smaller than the measured one, $\mathrm{T}_{4}$ is $26.1 \%$ less than the measured one and $\mathrm{T}_{5}$ it is $32.91 \%$ smaller than the measured one. The calculated values are almost the same as the measured data. Generally by using the above numerical model the simulated values agreed well with the observed data.

As described above, overall, the model replicates well these breach parameters.

\section{Conclusions}

The tests confirmed that headcut erosion plays a key role in the process of breach development in embankments constructed with cohesive materials. Then breach developments are classified in to five stages; at their different phases: initiation of erosion, flow shear erosion, migration erosion, undermining of the headcut due to imposing waterfall scour or sidewall bottom erosion, soil slope mass failure from the headcut of vertical and lateral erosion, and they all contribute to the breach development process. For the models constructed with sandy-clay, no different breach characteristics observed.

During breach development process in five stages, breach flow discharge and velocity rapidly increase from stage-1 to 2, similarly up to the end of stage-3, and gradually increase from the beginning of stage- 3 to the first part of stage- 4 , however, in all tests both are starts to drop from the end of stage- 4 to the final stage and then constant flow. In case breach width development process more or less gradually increases in all stages. Moreover, specifically at each stage the performance of model evaluated using RMSE , and quantified results for stage-1: 0.07, 0.6 , and $2.75 \%$, stage-2: $0.14,15.27$, and $11.98 \%$, stage- 3 : $0.47,18.32$, and $11.15 \%$, stage- $4: 0.40,15.46$, and $7.59 \%$ 
and stage-5: 3.93, 12.78 and 11.66 for the peak discharges, breach widths, and breach flow velocity respectively these parameters are reasonably well reproduced by the model.

The overall numerically calculated breach parameters agree well with the measured data, (82.5, 90.1, 78.6 and $85 \%$ ), of the test data have less than $25 \%$ errors, and the root-mean-square-errors are 11.02, 15.12, 21.82 and $27.57 \%$ on average for the calculated peak breach discharges, breach widths, breach flow velocity and breach characteristic times, respectively. The laboratory test illustrated that the evaluation of breach flow, breach width, and upstream water level is the most important consideration in the model. Due to numerous factors influencing the breaching formation and development in embankments

\section{References}

[1] Zhao, G., Visser, P. J., Peeters, P., Vrijling, J. K. "Headcut migration prediction of the cohesive embankment breach", Journal of Elsevier, Engineering Geology, 164, pp. 18-25, 2013.

https://doi.org/10.1016/j.enggeo.2013.06.012

[2] ASCE/EWRI Task Committee on Dam/Levee Breaching "Earthen Embankment Breaching", Journal of Hydraulic Engineering, 137(12), pp. 1549-1564, 2011.

https://doi.org/10.1061/(ASCE)HY.1943-7900.0000498

[3] Zhong, Q., Chen, S., Deng, Z. "Numerical model for homogeneous cohesive dam breaching due to overtopping failure", Journal of Mountain Science, 14, pp. 571-580, 2017.

https://doi.org/10.1007/s11629-016-3907-5

[4] Bennett, S. J., Alonso, C. V., Prasad, S. N., Römkens, M. J. M. "Experiments on headcut growth and migration in concentrated flows typical of upland areas", Water Resources Research, 36(7), pp. 1911-1922, 2000.

https://doi.org/10.1029/2000WR900067

[5] Morris, M. W., Hassan, M. A. A. M., Vaskin, K. A. "Conclusions and recommendations from the IMPACT Project WP2: Breach Formation", IMPACT, Rep. WP2_10Summary_v3_0, 2004. [Online] Available at: http://www.impact-project.net/wp2_technical.htm [Accessed: 15 December 2018]

[6] Vaskinn, K. A., Løvoll, A., Höeg, K., Morris, M., Hanson, G., Hassan, M. A. A. M. "Physical modeling of breach formation: Large scale field tests". presented at: Proceedings of Dam Safety 2004, Phoenix, AZ, USA, Sept. 26-30, 2004. [Online] Available at: https://pdfs.semanticscholar.org/29c4/fc2938493ad843240e87a6a6 3e9d1633847b.pdf [Accessed: 15 December 2018]

[7] Hanson, G. J., Cook, K. R., Hunt, S. L. "Physical modeling of overtopping erosion and breach formation of cohesive embankments", Journal of American Society of Agricultural Engineers, 48(5), pp. 1783-1794, 2005.

https://doi.org/10.13031/2013.20012 still no consensus and common understanding of the mechanism of embankment dam breaching. More experimental researches is necessary for a better understanding of the physics of embankment breach formation so that the present model can be subjected to further laboratory and field tests because of soils have different behaviors as well including model scale effect in embankment breach.

\section{Acknowledgment}

This research was supported by the Special Topics of National Key Research and Development Program of China (Grant Number 2018YFC1508801-4), China scholarship council (CSC No.2016DFH250), and Arba Minch University, Ethiopia.

[8] Zhang, J. Y., Li, Y., Xuang, G. X., Wang, X. G., Li, J. "Overtopping breaching of cohesive homogeneous earth dam with different cohesive strength", Journal of Science in China Series E: Technological Sciences, 52, pp. 3024-3029, 2009. https://doi.org/10.1007/s11431-009-0275-1

[8] Zhu, Y., Visser, P. J., Vrijling, J. K. "Review on embankment dam breach modeling", In: New Developments in Dam Engineering: Proceedings of the 4th International Conference on Dam Engineering, Nanjing, China, 2004, pp. 1189-1196. https://doi.org/10.1201/9780203020678.ch147

[9] Zhu, Y. H., Visser, P. J., Vrijling, J. K., Wang, G. Q. "Experimental investigation on breaching of embankments", Journal of China Technological Sciences, 54, pp. 148-155, 2011. https://doi.org/10.1007/s11431-010-4208-9

[10] Hahn, W., Hanson, G. J., Cook, K. R. "Breach morphology observations of embankment overtopping test", In: Joint Conference Water Resources Engineering and Water Resources Planning and Management, Minneapolis, USA, 2000, pp. 1-10. https://doi.org/10.1061/40517(2000)411

[11] Wu, W. "Technical Report, Introduction to DLBreach - A Simplified Physically-Based Dam/Levee Breach Model (Version 2016.4)", Clarkson University, New York, NY, USA, 2016. [Online] Available at: https://webspace.clarkson.edu/ wwu/ Reports/Technical\%20Report\%20of\%20DLBreach\%20Apr-2016 [Accessed: 21 December 2018]

[12] Morris, M. W. "Breaching of earth embankments and dams", Ph.D Thesis, The Open University, 2011. [Online] Available at: http://oro. open.ac.uk/id/eprint/54530 [Accessed: 23 December 2018]

[13] Fread. D. L. "BREACH: An erosion model for earthen dam failure", National Oceanic and Atmospheric Administration, Silver Spring, MD, USA, 1988. [Online] Available at: https://pdfs. semanticscholar.org/b19c/bd9f08ac7ea062c002acb 1 fdae 7 d8ab4b3ef.pdf?_ga=2.119327052.498590534.15801181861538662965.1542890682 [Accessed: 23 December 2018] 
[14] Wu, W. "Simplified Physically based Model of Earthen Embankment Breaching", Journal of Hydraulic Engineering, 139(8), pp. 837-851, 2013.

https://doi.org/10.1061/(ASCE)HY.1943-7900.0000741

[15] Zhu, Y. "Breach Growth in Clay Dikes", Ph.D Thesis, Delft University of Technology, 2006. [Online] Available at: [Accessed: 10 January 2019]

[16] Visser, P. J. "Breach growth in sand-dikes", Ph.D Thesis, Delft University of Technology, 1998. [Online] Available at: https:// repository.tudelft.nl/islandora/object/uuid\%3A3721e23b-d34c45a9-8b36-e5930462d8e2 [Accessed: 10 January 2019]
[17] Singh, V. P. "Dam Breach Modeling Technology", Springer, Dordrecht, Netherland, 1996.

https://doi.org/10.1007/978-94-015-8747-1

[18] Fread, D. L. "DAMBREAK: The NWS dam break flood forecasting model", National Oceanic and Atmospheric Administration, Silver Spring, MD, USA, 1980. [Online] Available at: https://fdocuments.net/document/dambrk-the-nws-dambreak-flood-forecastingmodel.html [Accessed: 13 January 2019] 